\title{
Effects of warming on a Mediterranean phytoplankton community
}

\author{
Silvia Pulina ${ }^{1}$, Andreas Brutemark ${ }^{2}$, Sanna Suikkanen ${ }^{3}$, Bachisio M. Padedda ${ }^{4}$, Lorena M. Grubisic ${ }^{5}$, \\ Cecilia T. Satta ${ }^{4}$, Tiziana Caddeo ${ }^{4}$, Pasqualina Farina ${ }^{4}$, Nicola Sechi ${ }^{4}$, and Antonella Lugliè ${ }^{4}$ \\ ${ }^{1}$ Department of Life and Environmental Science, University of Cagliari, Cagliari, 09126, Italy \\ ${ }^{2}$ Calluna AB, Stockholm, 11321, Sweden \\ ${ }^{3}$ Marine Research Centre, Finnish Environment Institute, Helsinki, 00560, Finland \\ ${ }^{4}$ Department of Architecture, Design and Urban Planning, University of Sassari, Sassari, 07100, Italy \\ ${ }^{5}$ Department of Ecology and Genetics, Limnology and Science for Life Laboratory, Uppsala University, \\ Uppsala, 75236, Sweden
}

Correspondence to: Silvia Pulina (pulinasi@uniss.it)

Received: 7 December 2015 - Revised: 21 March 2016 - Accepted: 6 April 2016 - Published: 22 April 2016

\begin{abstract}
Predicting the responses of organisms is a complex challenge especially when water temperature is expected to increase over the coming decades, as a result of global warming. In this work the effects of warming on phytoplankton communities were investigated. An indoor experiment was performed, where water from a Mediterranean lagoon was incubated at different temperatures. Three treatments were applied in triplicate incubation units: the control $\left(11^{\circ} \mathrm{C}\right), 3^{\circ} \mathrm{C}$ increase $\left(14^{\circ} \mathrm{C}\right)$, and $6^{\circ} \mathrm{C}$ increase $\left(17^{\circ} \mathrm{C}\right)$. Our results showed significant effects by warming on phytoplankton. The abundance of relatively smaller taxa (Chlorella sp. and Planktothrix agardhii-rubescens group) increased at $17^{\circ} \mathrm{C}$, whereas the abundance of relatively larger species (Cyclotella sp. and Thalassiosira sp.) decreased, compared with the control. This shift towards smaller taxa resulted in a higher total biomass but lower chlorophyll $a$ concentrations at the highest temperature.
\end{abstract}

\section{Introduction}

Aquatic ecosystem functioning is based on the activity of planktonic organisms which are linked by complex trophic, competitive, mutualistic and parasitic interactions (O’Connor et al., 2009). In particular, phytoplankton merits special attention being generally the dominant primary producer in most aquatic ecosystems. Situated at the base of the food web, phytoplankton is linked to the biogeochemical cycles and energy flux; all changes in phytoplankton composition, abundance and distribution may have cascading effects along the trophic food web (Barbosa et al., 2010). Phytoplankton is considered to be good indicators of climate change, which may alter the structure and dynamics of aquatic ecosystems (Hays et al., 2005). Water temperature is expected to increase in coming decades as a result of global warming, and predicting the consequent responses of organisms is a complex challenge (Giorgi and Lionello, 2008). Warming can impact plankton directly by eliciting physiological and adaptive responses, or indirectly by inducing changes in water circulation, stratification, and decreasing surface water viscosity (O'Neil et al., 2012). Understanding the effects of warming on plankton communities is extremely important since it may also contribute to financial losses in terms of human health as well as loss of recreational areas. For example, recent literature has predicted the future increase in potentially harmful phytoplankton blooms (harmful algal blooms, HABs) also in relation to climate change (Rigosi et al., 2015).

It is generally recognized that maximal growth rates of both autotrophic and heterotrophic organisms increase with temperature (Rose and Caron, 2007), which may lead to increases in both primary producer turnover rates and biodiversity, and reductions in average phytoplankton abundance and cell sizes over the next century (Boyce et al., 2015, and references therein). 
The overall aim of this work was to investigate the responses of a Mediterranean phytoplankton community exposed to experimental increase in temperature. Based on previous studies (Morán et al., 2010, and references therein), we hypothesized that warming would significantly affect phytoplankton abundance and composition, benefiting smaller species.

\section{Material and methods}

\subsection{Sampling and experimental setup}

Subsurface water was collected on the 10 February 2015 from the center of Cabras Lagoon (western Mediterranean Sea; $39^{\circ} 93^{\prime} 20^{\prime \prime} \mathrm{N}, 8^{\circ} 47^{\prime} 10^{\prime \prime} \mathrm{E}$ ). In situ, water was screened with a $200 \mu \mathrm{m}$ mesh to exclude mesozooplankton, and transferred immediately to the laboratory for incubations. An indoor experiment was carried out from 10 to 26 February 2015. Incubation units were placed in the same laboratory room and were settled next to each other. The position of each unit was the same for the whole duration of the experiment. Incubation units consisted of plastic buckets, $31 \mathrm{~cm}$ high and $29 \mathrm{~cm}$ in diameter. Each bucket was filled with $10 \mathrm{~L}$ of the lagoon mesh-filtered water, which was constantly and gently mixed using a small stirrer for aquaria. Light conditions simulating winter season (February) were applied: $400 \mu \mathrm{mol}$ photons $\mathrm{m}^{2} \mathrm{~s}^{-1}$ in a 10:14 light/dark cycle. An automatic system with "Peltier cells" was arranged to regulate and keep constant water temperature in each incubation unit. Temperature was monitored daily using a YSI ProPlus sensor.

Three treatments were applied in triplicate incubation units: (1) $11^{\circ} \mathrm{C}$, the control, i.e., present-day winter mean water temperature, based on long-term data from the study site; (2) $14{ }^{\circ} \mathrm{C}$, i.e., $3{ }^{\circ} \mathrm{C}$ increase in water temperature compared to control units, which is the expected temperature rise in the Mediterranean region in the coming century (Giorgi and Lionello, 2008); and (3) $17^{\circ} \mathrm{C}$, i.e., $6{ }^{\circ} \mathrm{C}$ increase in water temperature compared to control units, which is the expected temperature rise within two centuries (Giorgi and Lionello, 2008).

\subsection{Phytoplankton analyses}

A total of $10 \mathrm{~mL}$ of water for analysis of chlorophyll $a$ (Chl $a$ ) was collected everyday from each incubation unit, and the concentrations were measured using a fluorometer (Turner, Trilogy). Water for phytoplankton analyses was collected every 3 days (day 0 , T0; day 3, T1; day 6, T2, day 9, T3; day 13, T4; day 16, T5) from each incubation unit; $100 \mathrm{~mL}$ water samples were fixed with acid Lugol's solution and analyzed according to Utermöhl (1958), using an inverted microscope (Zeiss, Axiovert25), and $5 \mathrm{~mL}$ of water was settled for at least $4 \mathrm{~h}$, after which larger and more easily identifiable cells were counted at $100 \times$ magnification by scanning the entire bottom of the sedimentation chamber, whereas smaller species were counted at $200 \times$ or $400 \times$ magnification in an adequate number of fields (at least $10 \%$ of the total bottom area of the settling chamber). Species were identified according to the taxonomic literature listed in Pulina et al. (2012). Carbon biomass was estimated after determination of biovolume based on standard geometric shapes, by using the specific conversion factors indicated by Menden-Deuer and Lessard (2000).

\subsection{Statistical analyses}

A linear mixed-effects (LME) model was used to assess differences in Chl $a$ and phytoplankton community between temperatures, with temperature as fixed effect and day as random effect (Pinheiro et al., 2012). Statistical significance of the random effect $x$ day was assessed by comparing a generalized least squares (GLS) model without the random effect, with the final LME model. The comparison was performed using a likelihood ratio test (LRT). Distributional assumptions of linear models (normality and homoscedasticity of residuals) were checked for each response variable, and all data were log-transformed before analysis to meet the assumptions. Tukey's pairwise post hoc test was conducted to determine which of the effects of the explanatory factor differed significantly from each other (Lenth, 2016). The statistical analyses were carried out using the R 3.2.3 software ( $R$ Core Team, 2015).

\section{Results}

The Chl $a$ concentrations and total biomass values differed significantly between temperatures and days (Table 1). Chl $a$ increased from $\mathrm{T} 0$ to $\mathrm{T} 5$ in all treatments, with the only exception at $17^{\circ} \mathrm{C}$ from T4 to T5 (Fig. 1). The highest concentrations were detected at $11^{\circ} \mathrm{C}$, while the lowest were at $17^{\circ} \mathrm{C}$ for the entire duration of the experiment (Tukey test $p<0.04)$. At T5, the minimum value was $9.6 \pm 0.4 \mu \mathrm{g} \mathrm{L}^{-1}$, observed at $17^{\circ} \mathrm{C}$, and the maximum was $13.7 \pm 0.1 \mu \mathrm{g} \mathrm{L}-1$, observed at $11^{\circ} \mathrm{C}$. The phytoplankton biomass also increased from $\mathrm{T} 0$ to $\mathrm{T} 5$ in all treatments but in this case, the highest values were observed at $17^{\circ} \mathrm{C}$, while the lowest at $11^{\circ} \mathrm{C}$ (Tukey test $p<0.001$ ). At $\mathrm{T} 5$, the minimum value was $194.9 \pm 59.4 \mu \mathrm{g} \mathrm{CL}^{-1}\left(11^{\circ} \mathrm{C}\right)$, and the maximum was $372.7 \pm 100.8 \mu \mathrm{g} \mathrm{C} \mathrm{L}^{-1}\left(17^{\circ} \mathrm{C}\right.$; Fig. 1$)$.

Among phytoplankton, the class Chlorophyceae (mainly Chlorella sp., with a mean biovolume of $16.9 \mu^{3}$ ) was the most important in terms of contribution to total biomass, forming $>80 \%$ of total biomass at T0 in all treatments, and about $90 \%$ from $\mathrm{T} 1$ to $\mathrm{T} 5$ in all treatments. The Chlorophyceae biomass increased from $\mathrm{T} 0$ to $\mathrm{T} 5$ in all treatments, and differed significantly between temperatures and days (Table 1). The highest biomass values were observed at $17^{\circ} \mathrm{C}$ and the lowest at $11^{\circ} \mathrm{C}$ (Tukey test $p<0.01$ ), similarly to the total biomass. At T5, the minimum value 

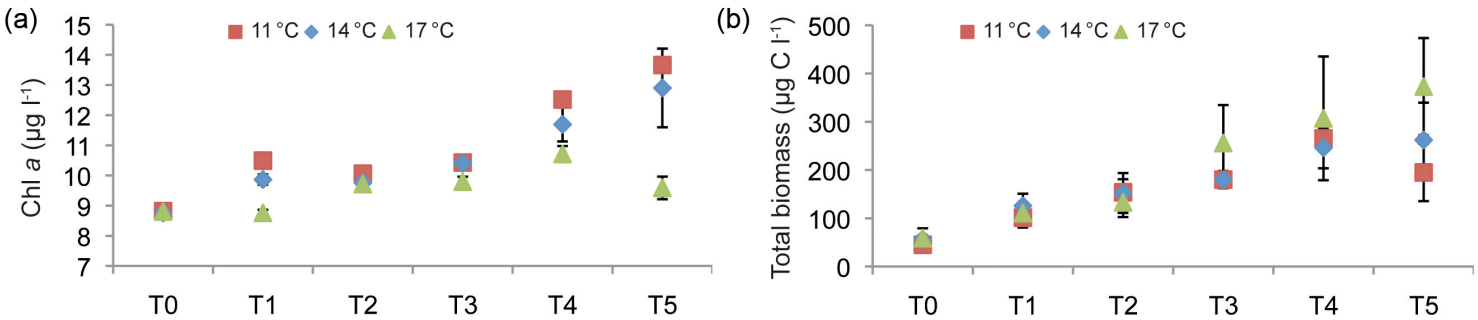

Figure 1. Chlorophyll $a$ concentrations (a) and total phytoplankton biomass (b) in the different temperature treatments $(n=3$, mean \pm SD).

Table 1. Results of linear mixed-effects model (LME) for each response variable, with temperature as fixed factor and day as random effect.

\begin{tabular}{llll}
\hline Response variable & Explanatory variable & $F$ & $P$ \\
\hline Chl $a$ & Temperature & 20.97 & $<0.001^{*}$ \\
& Day & NA & $<0.001^{*}$ \\
\hline Total biomass & Temperature & 3.24 & $0.048^{*}$ \\
& Day & NA & $<0.001^{*}$ \\
\hline Bacillariophyceae & Temperature & 9.50 & $<0.001^{*}$ \\
& Day & NA & $<0.001^{*}$ \\
\hline Chlorophyceae & Temperature & 5.06 & $0.010^{*}$ \\
& Day & NA & $<0.001^{*}$ \\
\hline Cyanophyceae & Temperature & 1.01 & 0.373 \\
& Day & NA & $<0.001^{*}$ \\
\hline
\end{tabular}

* significant effects. NA: not available.

was $177.6 \pm 61.3 \mu \mathrm{g} \mathrm{C} \mathrm{L}^{-1}\left(11^{\circ} \mathrm{C}\right)$, and the maximum was $362.3 \pm 101.0 \mu \mathrm{g} \mathrm{C} \mathrm{L}^{-1}\left(17^{\circ} \mathrm{C}\right)$. The class Bacillariophyceae (mainly Centrales: Cyclotella sp. and Thalassiosira sp., with mean biovolumes of 160.1 and $3761.9 \mu^{3}$, respectively) was the second most important group, contributing to total biomass by around $20 \%$ at the beginning of the experiment in all treatments. From T3 the contribution of Bacillariophyceae decreased over time to $\sim 5 \%$ of total biomass in all treatments. Bacillariophyceae biomass differed significantly between temperatures and days (Table 1): the highest values were observed at $11^{\circ} \mathrm{C}$ and the lowest at $17^{\circ} \mathrm{C}$ (Tukey test $p<0.001$ ). At $\mathrm{T} 5$, the minimum value was $1.0 \pm 0.6 \mu \mathrm{g} \mathrm{C} \mathrm{L}^{-1}\left(17^{\circ} \mathrm{C}\right)$, and the maximum was $9.2 \pm 3.1 \mu \mathrm{g} \mathrm{C} \mathrm{L}^{-1}\left(11^{\circ} \mathrm{C}\right)$. The class Cyanophyceae (mainly the Oscillatoriales: Planktothrix agardhii-rubescens group and Pseudanabaena catenata Lauterborn, with mean biovolumes of 25.8 and $12.3 \mu^{3}$, respectively, and the Nostocales: Aphanizomenon gracile Lemmermann, with a mean biovolume of $28.2 \mu^{3}$ ) was the third most important group, contributing with a total biomass of $\sim 10 \%$ at T0, and $\sim 5 \%$ from $\mathrm{T} 1$ to $\mathrm{T} 5$, in all treatments. The Cyanophyceae biomass increased from $\mathrm{T} 0$ to $\mathrm{T} 5$ in all treatments, and differed significantly between the sampled time points (Table 1). The highest values were observed at the higher temperatures and the lowest at $11^{\circ} \mathrm{C}$, even though the differences were not statistically significant (Table 1). At T5, the minimum value was $7.9 \pm 2.2 \mu \mathrm{g} \mathrm{C} \mathrm{L}^{-1}\left(11^{\circ} \mathrm{C}\right)$, and the maximum was $11.9 \pm 2.6 \mu \mathrm{g} \mathrm{C} \mathrm{L}^{-1}\left(14^{\circ} \mathrm{C}\right)$.

\section{Discussion and conclusions}

Experimental warming on a Mediterranean phytoplankton community showed that incubation at higher temperatures resulted in a higher total biomass but lower concentrations of Chl $a$. Chlorophyceae and Cyanophyceae were favored by warmer conditions, unlike Bacillariophyceae. Interpretation results were put into context in accordance to the following three ecological rules: (1) the temperature-size rule, i.e., the average size of individuals is inversely related to temperature (Atkinson et al., 2003); (2) the cross-community scaling relationship, i.e., total community abundance is inversely related to average organism size (White et al., 2007); and (3) the amount of Chl $a$ is related to cell volume and not cell number - thus bigger cells carry proportionately more chlorophyll than smaller ones (Reynolds, 2006). In our study, considering the dynamics of the species that contributed most to the total phytoplankton biomass, the abundance of relatively smaller taxa, such as Chlorella sp. and Planktothrix agardhii-rubescens group, increased at $17^{\circ} \mathrm{C}$, whereas the abundance of relatively larger species, such as Cyclotella sp. and Thalassiosira sp., decreased. The decrease in viscosity due to warming preferentially promoted the sinking of larger, non-motile phytoplankton with weak buoyancy regulation mechanisms, such as Bacillariophyceae (O'Neil et al., 2012, and references therein).

Prediction is not a simple task as such a kind of shift may result in the lagoon functioning. In fact, variation in the response of phytoplankton communities exposed to warming may be a consequence of differences in species composition or physiological status of the algae (Lindh et al., 2013). Furthermore, what is stressed in recent literature is the need for a more complete picture and consideration of the responses of the entire food web and interactions therein to describe and predict the complex and sometimes counterintuitive responses of plankton to global climate changes (Vidussi et al., 2011; Boyce et al., 2015). Although our results confirm previous observations reported worldwide on changes in phyto- 
plankton size composition (Morán et al., 2010), on the other hand, our observation on total phytoplankton biomass increased at higher temperature does not find unique interpretation. In fact, no significant effects due to warming were observed on the phytoplankton community of a Mediterranean lagoon, mainly due to changes in zooplankton composition and grazing activities during the highest temperatures (Vidussi et al., 2011). Indirect effects on phytoplankton communities due to warming were also observed for the Baltic Sea, where cell abundances were heavily reduced due to a strong grazing pressure (Lewandowska et al., 2014).

In conclusion, this work showed a shift in a Mediterranean phytoplankton community due to warming, increased abundance of smaller species, and a simultaneous decrease of larger species and Chl $a$. This study contributes to the knowledge on the effects of warming on phytoplankton communities, which is still scarce in marine and brackish environments, especially in the Mediterranean region.

Acknowledgements. We thank our colleagues at the UniSS DADU. Sanna Suikkanen was supported by the Academy of Finland (grant number 259357).

Edited by: R. Brandl

Reviewed by: R. Brandl and one anonymous referee

\section{References}

Atkinson, D., Ciotti, B. J., and Montagnes, D. J. S.: Protists decrease in size linearly with temperature: ca. $2.5 \%{ }^{\circ} \mathrm{C}^{-1}$, Proc. R. Soc. A, 270, 2605-2611, 2003.

Barbosa, A. B., Domingues, R. B., and Galvão, H. M.: Environmental forcing of phytoplankton in a Mediterranean Estuary (Guadiana Estuary, South-western Iberia): a decadal study of anthropogenic and climatic influences, Estuar. Coast., 33, 324-341, 2010.

Boyce, D. G., Frank, K. T., Worm, B., and Leggett, W. C.: Spatial patterns and predictors of trophic control in marine ecosystems, Ecol. Lett., 18, 1001-1011, 2015.

Giorgi, F. and Lionello, P.: Climate change projections for the Mediterranean region, Global. Planet. Change, 63, 90-104, 2008.

Hays, G. C., Richardson, A. J., and Robinson, C.: Climate change and marine plankton, Trends Ecol. Evol., 20, 337-344, 2005.

Lenth, R. V: lsmeans: Least-Squares Means, R package version 2.22, available at https://CRAN.R-project.org/package=lsmeans, last access: 17 March 2016.

Lewandowska, A. M., Hillebrand, H., Lengfellner, K., and Sommer, U.: Temperature effects on phytoplankton diversity - The zooplankton link, J. Sea Res., 85, 359-364, 2014.
Lindh, M. V., Riemann, L., Baltar, F., Romero-Oliva, C., Salomon, P. S., Graneli, E., and Pinhassi, J.: Consequences of increased temperature and acidification on bacterioplankton community composition during a mesocosm spring bloom in the Baltic Sea, Environ. Microbiol. Rep., 5, 252-262, 2013.

Menden-Deuer, S. and Lessard, E. J.: Carbon to volume relationships for dinoflagellates, diatoms, and other protist plankton, Limnol. Oceanogr., 45, 569-579, 2000.

Morán, X. A. G., López-Urrutia, A., Calvo-Díaz., A., and Li, W. K. W.: Increasing importance of small phytoplankton in a warmer ocean, Glob. Change Biol., 16, 1137-1144, 2010.

O'Connor, M. I., Piehler, M. F., Leech, D. M., Anton, A., and Bruno, J. F.: Warming and resource availability shift food web structure and metabolism, PLoS Biol., 7, 1-6, 2009.

O’Neil, J. M., Davis, T. W., Burford, M. A., and Gobler, C. J.: The rise of harmful cyanobacteria blooms: the potential roles of eutrophication and climate change, Harmful Algae, 14, 313-334, 2012.

Pinheiro, J., Bates, D., DebRoy, S., and Sarkar, D.: R Development Core Team, nlme: Linear and nonlinear mixed effects models, $\mathrm{R}$ package version 3.1-105, 2012.

Pulina, S., Padedda, B. M., Satta, C. T., Sechi N., and Lugliè, A.: Long term phytoplankton dynamics in a Mediterranean eutrophic lagoon (Cabras Lagoon, Italy), Plant Biosyst., 146, 259-272, 2012.

R Core Team: R: A Language and Environment for Statistical Computing, R Foundation for Statistical Computing, Vienna, Austria, available at: http://www.R-project.org/ (last access: 18 March 2016), 2015.

Reynolds, C. S.: Ecology of phytoplankton, Cambridge University Press, Cambridge, United Kingdom, 552 pp., 2006.

Rigosi, A., Hanson, P., Hamilton, D. P., Hipsey, M., Rusak, J. A., Bois, J., Sparber, K., Chorus, I., Watkinson, A. J., Qin, B., Kim, B., and Brookes, J. D.: Determining the probability of cyanobacterial blooms: the application of Bayesian networks in multiple lake systems, Ecol. Appl., 25, 186-199, 2015.

Rose, J. and Caron, D.: Does low temperature constrain the growth rates of heterotrophic protists? Evidence and implications for algal blooms in cold waters, Limnol. Oceanogr., 52, 886-895, 2007.

Utermöhl, H.: Zur vervollkommung der quantitativen phytoplankton-methodik, Mitt. Internat. Verein. Limnol., 9, 1-39, 1958.

Vidussi, F., Mostajir, B., Fouilland, E., Le Floc'h, E., Nouguier, J., Roques, C., Got, P., Thibault-Botha, D., Bouvier, T., and Trousselliera, M.: Effects of experimental warming and increased ultraviolet $\mathrm{B}$ radiation on the Mediterranean plankton food web, Limnol. Oceanogr., 56, 206-218, 2011.

White, E. P., Ernest, S. K. M., Kerkhoff, A. J., and Enquist, B. J.: Relationships between body size and abundance in ecology, Trends Ecol. Evol., 22, 323-330, 2007. 